Article

\title{
Physiological and Oxidative Stress Responses of Lettuce to Cleomside A: A Thiohydroximate, as a New Allelochemical from Cleome arabica $\mathrm{L}$.
}

\author{
Afef Ladhari ${ }^{1,2, *}$, Anna Andolfi ${ }^{2,3}$ (D) and Marina DellaGreca ${ }^{2}$ (D) \\ 1 Laboratoire GREEN-TEAM (LR17AGR01), Institut National Agronomique de Tunisie (INAT), \\ Universite de Carthage, 43 Avenue Charles Nicolle, Tunis 1082, Tunisia \\ 2 Dipartimento di Scienze Chimiche, Università Federico II, Complesso Universitario Monte S. Angelo, \\ via Cintia, 4, 80126 Napoli, Italy; andolfi@unina.it (A.A.); dellagre@unina.it (M.D.) \\ 3 BAT Center-Interuniversity Center for Studies on Bioinspired Agro-Environmental Technology, \\ University of Napoli 'Federico II', 80138 Naples, Italy \\ * Correspondence: afef.ladh@yahoo.fr; Tel.: +216-222-13830
}

Received: 7 September 2020; Accepted: 26 September 2020; Published: 28 September 2020

\begin{abstract}
The inclination toward natural products have led the onset for the discovery of new bioactive metabolites that could be targeted for specific therapeutic or agronomic applications. This study aimed to isolate bioactive compounds from Cleome arabica L., and subsequently determine the unexplored mechanism of action of the newly identified compounds on Lactuca sativa L. Chemical investigation of the ethyl acetate fraction of methanolic silique extract of $C$. arabica afforded seven secondary metabolites belonging to different classes such as flavonoids, triterpene, and a new thiohydroximate derivative, named cleomside A. Among phytotoxic assays, the growth of lettuce was totally inhibited by cleomside A compared to the other identified compounds. This effect was associated with the increased levels of electrolyte leakage, malondialdehyde, and hydrogen peroxide indicating disruption of membrane integrity and induction of oxidative stress. Activities of the antioxidant enzymes SOD, CAT, and APX were also elevated, thereby demonstrating the enhanced generation of reactive oxygen species upon identified allelochemical exposure. Thus, the changes caused by cleomside A described herein can contribute to better understanding the allelochemical actions of thiohydroximate and the potential use of these substances in the production of natural herbicides compared to the other identified flavonoids and triterpene.
\end{abstract}

Keywords: allelochemicals; Cleome arabica; thiohydroximate; oxidative damage; membrane integrity

\section{Introduction}

In the agricultural field, many invasive species have demonstrated resistance to commercially available herbicides, which cause about $32 \%$ of yield reduction, and therefore lead to huge economic losses [1]. Meanwhile, the production of synthetic herbicides was declined since the last two decades due to the absence of the discovery of a new target site of action [2]. In the last few years, many efforts have been devoted in order to discover an alternative natural phytotoxic product that might help in resolving the dependency on synthetic herbicides in a safety way considering the environment and human health $[2,3]$. Generally, many phytotoxic products are isolated and identified from different plant tissues, and to shed light on these phytotoxic compounds, it is important to discover new natural components with new target site that could offer interesting templates for potential pharmaceutical and agricultural applications [4].

Cleome arabica L. (genus Cleome) an annual herb in the family of Capparidaceae, is abundant in sandy environments, and the gravel, and stony grounds in arid Tunisia. This plant possesses 
important pharmaceutical, economic, and ecologic values. In addition, according to our previous studies [3], different tissues of C. arabica possessed potent phytotoxic effect mainly by the silique, that might be an alternative to develop natural herbicides for a sustainable agriculture. Besides that, it was noted that their dried parts are markedly browsed and appreciated by animals but are generally denied when it is fresh plant. This repulsion seems to be explained by the presence of certain repellant toxic compounds. Over the years, limited phytochemical investigation of $C$. arabica led to the isolation of phenolic compounds, alkaloids [5], dammarane triterpene [3-6], cleomin [7], new steroid derivatives [8], and glucosylated and rhamnosylated flavonols [9]. In fact, glucosinolates are the major organoleptic and bioactive constituents of the Capparidaceae, Brassicaceae and a few other related plant families $[10,11]$. Glucosinolates compounds have long been known for their fungicidal, bactericidal, nematocidal and allelopathic properties, and have recently attracted attention researchers because of their cancer chemoprotective attributes [12]. Although, scientists highlighted the negative aspects of glucosinolate compounds because of the prevalence of certain "antinutritional" or goitrogenic glucosinolates degradation products, and ultimately affect the productivity of animals [13]. Since there are very few studies on the identified active compounds form C. arabica, it is crucial to continue discovering new bioactive allelochemicals from the most active plant organ [3] that could promote new target site of action. Correlating the phytotoxicity assays with the physiological effect could understand deeper the mechanism of action of the active compound of C. arabica [14]. Actually, there are no work in the literature that correlate the main phytotoxic effects of $C$. arabica compounds with cellular events related to physiological, cytological, and antioxidant enzymes activities. Subsequent studies on the mode of action of the allelochemical stress could cause an oxidative damage, proved by membrane lipid peroxidation as well as an increase in antioxidant enzymes with a marked enhancement of the reactive oxygen species (ROS) [15]. Based on this evidence, we intended to investigate more about the effects of allelochemicals produced by $\mathrm{C}$. arabica on the antioxidant system, and if an imbalance in early germination stages could be related with the root inhibition, as well as to answer if this stress induced either defense or cell death responses. For these reasons, the present study aimed to identify new active allelochemicals from siliquae as the active organ of $C$. arabica. Then, we analyzed the effects of allelopathic stress caused by $C$. arabica extract and its identified compounds on Lactuca sativa L. at the physiological and cytological levels, particularly on activities of the antioxidant enzymes such as catalase (CAT), ascorbate peroxidase (APX), and superoxide dismutase (SOD). In addition, the hydrogen peroxide amount $\left(\mathrm{H}_{2} \mathrm{O}_{2}\right)$ and membrane damage as lipid peroxidation were determined.

\section{Results and Discussion}

\subsection{Structural Elucidation of Secondary Metabolites}

Repeated chromatographic purification of methanol extract of $C$. arabica yield to isolation of an unusual indole derivative (compound 1) whose structure was assigned by extensive spectroscopic analysis and six know compounds (2-7, Figure 1). Compound 1 (Figure 1) was obtained as light-yellow oil and showed bands at $\lambda_{\max } 207,268$ and $304 \mathrm{~nm}$ in UV spectrum. The structure of this compound was determined on the basis of spectroscopic data (Supplementary Materials Figures S1-S7). The molecular formula $\mathrm{C}_{17} \mathrm{H}_{22} \mathrm{~N}_{2} \mathrm{O}_{7} \mathrm{~S}$ was suggested by positive molecular peak at $m / z 399.1218[\mathrm{M}+\mathrm{H}]^{+}$in its HRESI-MS (Figure S8) and ${ }^{13} \mathrm{C}$ NMR spectra corresponding to eight degrees of unsaturation. The ${ }^{1} \mathrm{H}$ NMR (Table 1) displayed a methyl signal at $\delta$ H 2.24 as singlet, two methylene signals, of which one as two double doublets at $\delta \mathrm{H} 3.92(J=13.5,10.2 \mathrm{~Hz})$ and $3.75(J=12.0,5.4 \mathrm{~Hz})$ and one as two doublets at $\delta \mathrm{H} 4.78$ and $4.50(\mathrm{~J}=14.4 \mathrm{~Hz})$, and five methine signals, of which one as doublet at $\delta \mathrm{H}$ $5.10(\mathrm{~J}=7.1 \mathrm{~Hz})$ and four as multiplets in the $\delta \mathrm{H} 3.61-3.40$ range in the aliphatic region. The ${ }^{1} \mathrm{H} \mathrm{NMR}$ (Table 1) also displayed four signals at $\delta \mathrm{H} 7.10,7.02(\times 2)$ and 6.80 in the aromatic region. The ${ }^{13} \mathrm{C}$ NMR (DEPT, Table 1) spectrum indicated that compound 1 possesses 16 carbon signals, involving one methyl, two methylenes, nine methines (including four aromatics), and five quaternary carbons. 


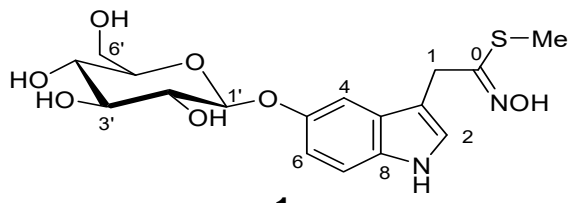

1<smiles>[R][14C]([R])Oc1c(-c2ccc(O)cc2)oc2cc(OC3OC(C)C(O)C(O)C3O)cc(O)c2c1=O</smiles>

3

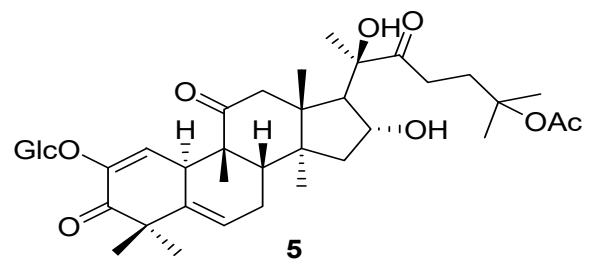<smiles>COc1c(OC)c(OC)c2c(=O)c(OC)c(-c3ccc(O)cc3)oc2c1OC</smiles>

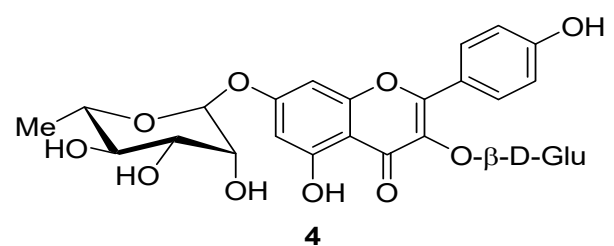<smiles>COc1cc2oc(-c3ccc(O)cc3)c(OC)c(=O)c2c(O)c1OC</smiles><smiles>COc1c(O)c(O)c2c(=O)c(OC)c(-c3ccc(O)cc3)oc2c1O</smiles>

Figure 1. Structures of compounds 1-7 isolated from the silique of Cleome arabica.

Table 1. ${ }^{1} \mathrm{H}$ and ${ }^{13} \mathrm{C}$ NMR spectral data of $\mathbf{1}$ (in methanol-d4, ${ }^{1} \mathrm{H}: 500 \mathrm{MHz},{ }^{13} \mathrm{C}: 125 \mathrm{MHz}$.

\begin{tabular}{cccc}
\hline No. & & \multicolumn{1}{c}{$\mathbf{~}$} & \\
\hline & $\delta$ C (mult.) & $\delta \mathbf{H}^{\mathbf{a}}$ & HMBC Correlations \\
\hline $\mathrm{SMe}$ & $12.6(\mathrm{q})$ & $2.24 \mathrm{~s}$ & \\
0 & $171.0(\mathrm{~s})$ & & $0,2,3,9$ \\
1 & $39.0(\mathrm{t})$ & $4.50, \mathrm{~d}(14.4)$ & $1,3,8,9$ \\
2 & $124.7(\mathrm{~d})$ & $7.10, \mathrm{~s}$ & $5,8,9$ \\
3 & $113.5(\mathrm{~s})$ & & \\
4 & $107.8(\mathrm{~d})$ & 7.02 (overlapped) & $4,7,8$ \\
5 & $153.5(\mathrm{~s})$ & & 5,8 \\
6 & $104.9(\mathrm{~d})$ & $6.80, \mathrm{br} \mathrm{d}(7.1)$ & \\
7 & $123.9(\mathrm{~d})$ & $7.02($ overlapped) & $5,3^{\prime}$ \\
8 & $140.5(\mathrm{~s})$ & & $4^{\prime}$ \\
9 & $119.0(\mathrm{~s})$ & $5.10, \mathrm{~d}(7.1)$ & $5^{\prime}$ \\
$1^{\prime}$ & $102.5(\mathrm{~d})$ & $3.53, \mathrm{~m}$ & $6^{\prime}$ \\
$2^{\prime}$ & $75.8(\mathrm{~d})$ & $3.44, \mathrm{~m}$ & $1^{\prime}$ \\
$3^{\prime}$ & $78.8(\mathrm{~d})$ & $3.42, \mathrm{~m}$ & $5^{\prime}$ \\
$4^{\prime}$ & $72.0(\mathrm{~d})$ & $3.61, \mathrm{~m}$ & \\
$5^{\prime}$ & $78.8(\mathrm{~d})$ & $3.92, \mathrm{dd}(13.5,10.2)$ & \\
$6^{\prime}$ & $63.1(\mathrm{t})$ & $3.75, \mathrm{dd}(12.0,5.4)$ & \\
& & &
\end{tabular}

${ }^{\text {a }}$ Coupling constants are given in parentheses, $J$ in $\mathrm{Hz}$.

The protons were assigned to the corresponding carbons by an HSQC experiment (Table 1). The COSY spectrum indicated the presence of a hexose unit, which on the basis of the ${ }^{1} \mathrm{H}$ and ${ }^{13} \mathrm{C}$ chemical shifts and coupling constants of anomeric proton was identified as $\beta$-O-glucopyranoside [16]. 
The aromatic portion was identified as indolic unit on the basis of ${ }^{1} \mathrm{H}$ and ${ }^{13} \mathrm{C}$ chemical shifts and long-range heterocorrelations observed in the HMBC spectrum (Figure 2). The most important correlations observed for the indole were: the protons at $\delta 7.10$ and 7.02 attributed to the $\mathrm{H}-2, \mathrm{H}-4$, and $\mathrm{H}-7$ respectively with the $\mathrm{C}-8$ carbon at $\delta 140.5$, and the first proton was also correlated to the $\mathrm{sp}^{3}$ carbon at $\delta 39.0(\mathrm{C}-1), \mathrm{C}-3(\delta 113.5)$, and C-9 ( $\delta 119.0)$ carbons; the H-7 proton was also correlated to the C-5 ( $\delta 153.5)$, carbon as well as the H-6 proton $(\delta 6.80)$ gave cross peaks with the C-4, C-7 $(\delta 123.9)$ and $\mathrm{C}-8$ carbons. In the HMBC spectrum heterocorrelation of the anomeric proton at $\delta 5.10$ with the C-5 carbon was observed indicating that the compound was glucosylated on indole. Beside the already reported correlations, the $\mathrm{H}-1$ and methyl protons were correlated to the $\mathrm{C}-0(\delta 171.0)$ defining a methyl $N$-hydroxyimidothioate group. NOESY spectrum evidenced correlation between the anomeric proton $(\delta 5.10)$ and aromatic proton at $\delta 6.80$ and $\mathrm{H}-5^{\prime}$ ( $\left.\delta 3.61\right)$. All these data led to the structure of methyl $N$-hydroxy-2-(5'-O- $\beta$-D-glucopyranosyl)-1H-indol-3-yl)ethanimidothioate (1) named cleomside A.

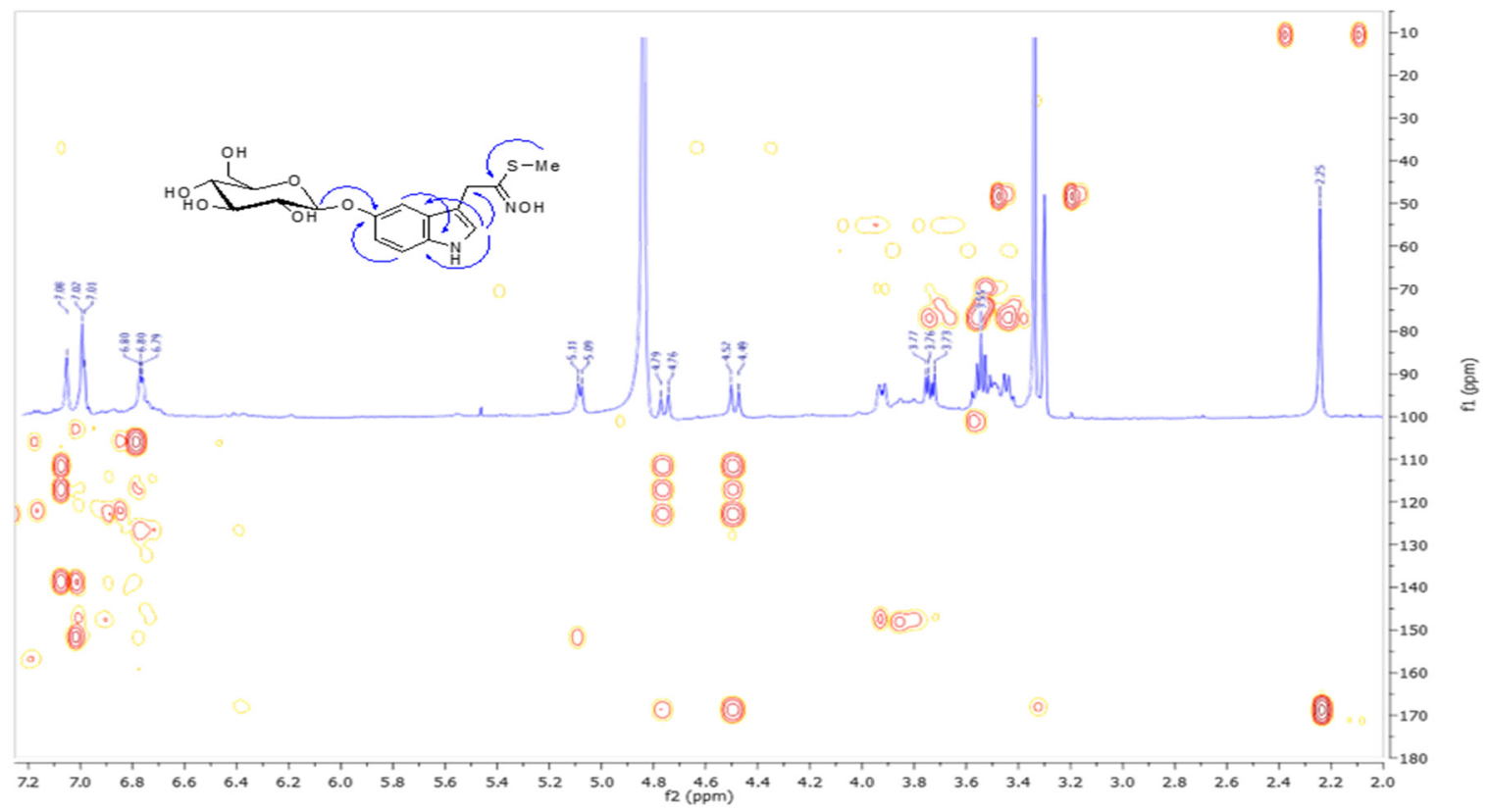

Figure 2. HMBC spectrum of cleomside A (1).

The flavonoid nature of compounds 2, 3, 4, 6 and 7 (Figure 1) was inferred from the analysis of spectral data, especially ${ }^{1} \mathrm{H}$ - and ${ }^{13} \mathrm{C}$ - spectra, that allowed us to elucidate their structures. 5,4'-Dihydroxy-3,6,7,8-tetramethoxyflavone (calycopterin, 2), kaempferol 3,7-O- $\alpha$-L-dirhamnopyranoside (kaempferitrin, 3), kaempferol 3-O- $\beta$-D-glucopyranoside-7-O- $\alpha$-L-rhamnopyranoside (4), 5,4'-dihydroxy3,6,7 -trimethoxyflavone (penduletin, 6), 5,6,4' -trihydroxy-3,7,8-trimethoxyflavone (7), were identified by comparison of their spectral data with those reported in literature [17,18].

Compound 5 was identified as a triterpene belong to cucurbitane group. Inspection of ${ }^{1} \mathrm{H}$ - and ${ }^{13} \mathrm{C}-\mathrm{NMR}$ spectra revealed that this compound possess a monosaccaride unit. The ${ }^{13} \mathrm{C}-\mathrm{NMR}$ spectrum of 5 displayed 36 carbon signals, of which 30 were attributed to the triterpenoid moiety and six to the sugar moiety. Thus, compound was identified as 25-O-acetylbryoamaride (Figure 1) by comparison of its NMR data with values reported in the literature [19].

\subsection{Phytotoxicity Assays}

The conducted analysis revealed that all the treatments possesses a significant phytotoxic effect on lettuce germination and growth. The inhibitory magnitude was varied according to the concentration of the tested samples (Table 2; Figure 3). In fact, all the treatments had similar frequency of germinated lettuce compared to the control, except those exposed to compounds $\mathbf{1}$ (cleomoside A) and 5 (25-O-acetylbryoamaride), which had an inhibition of $100 \%$ at the highest concentration 
(Table 2). The significant effect of compound 1 was markedly depicted even at the lowest concentration by an inhibition of $73.7 \%$ compared to the compound 5 (34.7\%). In addition, the compound 1 and 5 revealed the lowest $\mathrm{IC}_{50}$ values, which were estimated less than $50 \mu \mathrm{g} \mathrm{mL} \mathrm{m}^{-1}$ and $91.4 \mu \mathrm{g} \mathrm{mL} \mathrm{m}^{-1}$, respectively. While, the EtOAc extract and the other tested compounds possess $\mathrm{IC}_{50}$ values greater than $800 \mu \mathrm{g} \mathrm{mL}^{-1}$.

Table 2. Effect of silique ethyl acetate extract of C. arabica and its identified compounds (C1-C7) on germination index, for seven days, expressed in \% of control of lettuce.

\begin{tabular}{|c|c|c|c|c|c|c|c|}
\hline & \multicolumn{7}{|c|}{ Concentrations $\left(\mu \mathrm{g} \mathrm{mL}^{-1}\right)$} \\
\hline & Treatments & 50 & 100 & 200 & 400 & 800 & $\mathrm{IC}_{50}$ \\
\hline \multirow{8}{*}{ Compounds } & EtOAc Extract & $89.3 \pm 3.4^{c}$ & $77.6 \pm 1.5^{c}$ & $70.7 \pm 4.9^{c}$ & $69.6 \pm 1.3^{c}$ & $71.9 \pm 3.6^{b}$ & $>800$ \\
\hline & 1 & $26.3 \pm 2.1^{a}$ & $25.1 \pm 1.7^{\mathrm{a}}$ & $15.3 \pm 0.9^{\mathrm{a}}$ & $00.0 \pm 0.0^{\mathrm{a}}$ & $00.0 \pm 0.0^{\mathrm{a}}$ & $<50$ \\
\hline & 2 & $93.2 \pm 1.4^{\mathrm{c}}$ & $90.7 \pm 5.6^{d}$ & $89.6 \pm 1.2^{d}$ & $91.3 \pm 2.6^{\mathrm{d}}$ & $70.4 \pm 5.1^{b}$ & $>800$ \\
\hline & 3 & $86.3 \pm 4.3^{c}$ & $80.4 \pm 4.7^{c}$ & $78.7 \pm 2.7^{c}$ & $66.3 \pm 3.6^{c}$ & $60.4 \pm 3.9^{b}$ & $>800$ \\
\hline & 4 & $93.6 \pm 2.9^{c}$ & $86.7 \pm 4.3^{c}$ & $82.9 \pm 3.9^{d}$ & $80.4 \pm 3.4^{\mathrm{d}}$ & $77.3 \pm 5.3^{b}$ & $>800$ \\
\hline & 5 & $65.3 \pm 3.4^{b}$ & $51.1 \pm 3.6^{b}$ & $30.4 \pm 1.6^{b}$ & $25.0 \pm 2.3^{b}$ & $00.0 \pm 0.0^{\mathrm{a}}$ & 91.4 \\
\hline & 6 & $96.3 \pm 4.9^{c}$ & $94.2 \pm 5.4^{\mathrm{d}}$ & $94.6 \pm 4.3^{d}$ & $88.2 \pm 3.2^{d}$ & $80.4 \pm 4.1^{b}$ & $>800$ \\
\hline & 7 & $93.4 \pm 3.6^{c}$ & $93.7 \pm 4.6^{\mathrm{d}}$ & $91.9 \pm 6.4^{\mathrm{d}}$ & $90.7 \pm 5.4^{\mathrm{d}}$ & $90.7 \pm 2.6^{c}$ & $>800$ \\
\hline
\end{tabular}

Note: The same letter indicates no significant differences $p<0.05$ (LSD test).
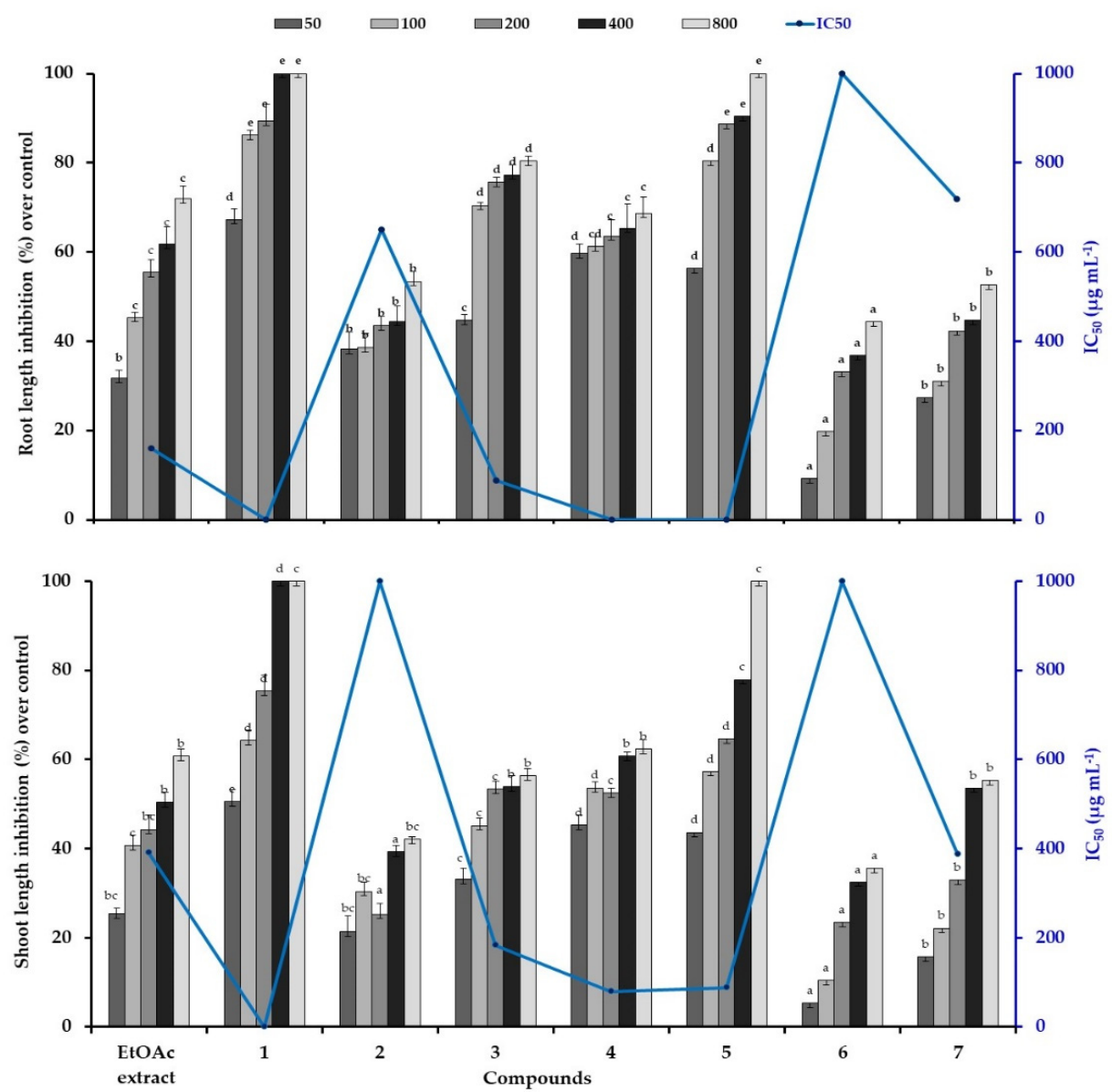

Figure 3. Phytotoxic effect of silique ethyl acetate extract of $C$. arabica and its identified compounds on root/shoot length of lettuce at different concentration $\left(50,100,200,400,600\right.$, and $\left.800 \mu \mathrm{gL}^{-1}\right)$. The bars on each column show standard error. Values $(N=3 \pm$ S.E.). Different letters in columns indicate significant differences among treatments at $p<0.05$ (LSD test). 
Similarly, the compounds 1 and 5 exerted the highest phytotoxic effect on lettuce growth indicated by a total inhibition from 400 and $800 \mu \mathrm{g} \mathrm{mL}{ }^{-1}$, respectively (Figure 3). In all cases, the root length was more sensitive than shoot, particularly in the presence of EtOAc extract, the compounds 3 and 4 in which they revealed an average inhibition of $73.6 \%$ and $59.7 \%$ for root and shoot lengths, respectively, at the highest concentration. While, the other compounds exhibited moderate inhibition of $47.2 \%$ on lettuce seedling growth. Thus, the highest phytotoxic effect of the active compounds was displayed by the lowest $\mathrm{IC}_{50}$ values, which was estimated under $50 \mu \mathrm{g} \mathrm{mL} \mathrm{m}^{-1}$ in the presence of the compound 1 for root and shoot lengths. Similarly, the compounds 4 and 5 possess the lowest $\mathrm{IC}_{50}$ values (under $50 \mu \mathrm{g} \mathrm{mL}^{-1}$ ) for root lengths and was about $83.8 \mu \mathrm{g} \mathrm{mL}^{-1}$ for shoot lengths. The EtOAc extract and the compound 7 revealed $\mathrm{IC}_{50}$ value of $389 \mu \mathrm{g} \mathrm{mL}^{-1}$, while the compound 3 possess a value of $183 \mu \mathrm{g} \mathrm{mL} \mathrm{m}^{-1}$. However, the highest $\mathrm{IC}_{50}$ value was estimated about more than $800 \mu \mathrm{g} \mathrm{mL}^{-1}$ by the compounds 6 and 2 (Figure 3).

Generally, in response to various tested flavonoids, germination was slightly affected, whereas significant difference was observed against radical elongation. It could be explained by the entry of water through the integument during the germination process produced the entry of bioactive compounds, by mass flow, which began their physiological activities in the next phase of root growth [20]. While, the identified triterpene (compound 5) and thiohydroximate (compound 1) induced the highest phytotoxic effect even at the lowest concentration While, the identified triterpene (compound 5) and thiohydroximate (compound 1) induced the highest phytotoxic effect even at the lowest concentration. To our knowledge there is no study considering the phytotoxic effect of these identified compounds neither on germination nor on seedling growth. Our results confirmed earlier studies by showing that some thiohydroximate derivatives can be phytotoxic at high concentrations. It was noted that thiohydroximates occur most commonly as precursors of glucosinolates, important plant natural products [21]. Besides that, the knowledge of flavonoids involved in plant-plant interactions and their mechanisms of action are poor and, moreover, the structural characteristics required for these biological activities are scarcely known. The marked phytotoxic effect of terpenoids compared to flavonoids was confirmed by Ladhari et al. [3], which they revealed that the identified terpenoid in C. arabica silique induced an important inhibition of 70\% compared to calycopterin (inhibition of 33\%) on lettuce growth at $0.06 \mathrm{~g} \mathrm{~L}^{-1}$. Some flavonoids appear to act primarily as germination and cell growth inhibitors, possibly through interference with the energy transfer system within the cell [22]. Flavones have been shown to interfere with ATP formation in plant mitochondria [23]. Modifications of plant growth and development in response to exposure to allelochemicals may reflect alterations in the molecular biology of cells, their ultrastructure, or their biochemical and physiological processes, which have been the focus of some reviews [24]. Often, allelochemicals effects are reported descriptively, missing integrative models to explain how these molecules could affect cellular processes.

\subsection{Mitotic Index in Lettuce Roots}

The inhibitory effect of the tested treatments was depicted from the lowest concentration of $50 \mu \mathrm{g} \mathrm{mL}^{-1}$ after 7 days (Figure $4 \mathrm{~A}$ ). Besides that, the macroscopic investigation revealed that the phytotoxic effect was markedly increased in the following order: Compounds $\mathbf{6}<\mathbf{7}<\mathbf{2}<$ EtOAc extract $<4<3<5<1$, but without any morphological change neither on the roots nor on shoots. In addition, the microscopic investigation was carried out in the presence of EtOAc extracts of C. arabica and its identified compounds (1-7) tested the lowest concentration of $50 \mu \mathrm{g} \mathrm{mL}^{-1}$ on lettuce seeds for $48 \mathrm{~h}$ at (Figure 4B). The inhibitory effect of the extract and the identified compounds were further confirmed by microscopic studies involving determination of mitotic index reduction. The results showed that the compounds 1 and 5 reduced significantly the cell division through a marked decline in the mitotic index of $75.5 \%$ and $68.5 \%$, respectively. It was noted also that the EtOAc extract and compounds 3 and 4 decreased the mitotic index by an inhibition of $51.6 \%$, while this reduction did not exceed $30 \%$ for the remained treatments. 

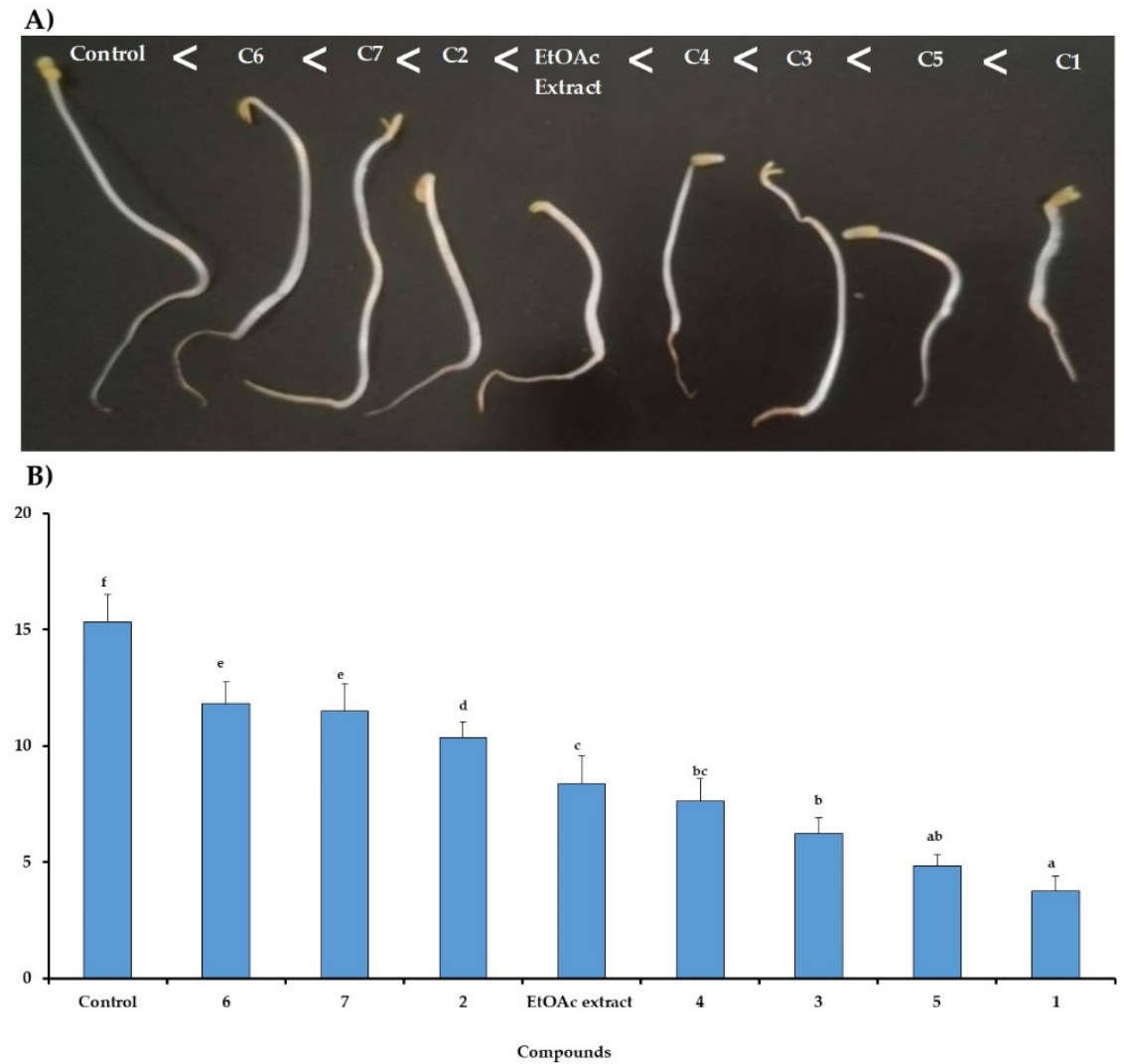

Figure 4. Relationship between mitotic index during $48 \mathrm{~h}(\mathrm{~A})$ and morphological responses in 7 days (B) to EtOAc extract of C. arabica and its identified compounds (C1-C7) at $50 \mu \mathrm{g} \mathrm{mL}^{-1}$ on seedling growth of lettuce. The bars on each column show standard error. Values ( $N=3 \pm$ S.E.). Different letters in columns indicate significant differences among treatments at $p<0.05$ (LSD test).

According to our previous results [3], the mito-depressive effect could be attributed to the phytotoxic isolated compounds from silique of $C$. arabica. Thus, the present study revealed, the identified allelochemicals, compounds $\mathbf{1}$ and $\mathbf{5}$, were considered the major depressor of the mitotic index compared to the other identified compounds. In fact, the mitotic index measures the proportion of cells in the M-phase of the cell cycle and its inhibition could be explained as cellular death or a delay in the cell proliferation kinetics [25]. It was noted that some allelochemicals affected the mitotic process, particularly the $\mathrm{G}_{2}-\mathrm{M}$ checkpoint of lettuce, and reduced the number of cells in each cell division period $[26,27]$. Subsequently, they could affect the DNA synthesis by damaging the tubulins and resulting in polyploid nuclei [26-28]. Moreover, the phytotoxic action of the identified compound could be explained the influence of numerous physiological and metabolic processes.

\subsection{Oxidative Stress Markers}

\subsubsection{Membrane Integrity}

The membrane damage in lettuce under the EtOAc silique extract and its identified compounds was estimated through relative electrolyte leakage (EL) and malondialdehyde (MDA) production (Table 3). The degree of cell membrane injury was perceived by an increase of the electrolyte leakage and malondialdehyde in whole plant of lettuce under all treatment cases. This obvious stimulation was markedly revealed by an average increase of $38.8 \%$ in lettuce under the compounds $\mathbf{1}, \mathbf{3}$, and $\mathbf{5}$. The EL and MDA level were induced by an increment of $17.6 \%$ and $26.9 \%$, respectively, under EtOAc extract, compounds 2 and 4, but did not exceed 7.9\% when the plant treated by the compound 7 . However, the compound $\mathbf{6}$ reduced the amount of major lipid peroxidation products and electrolyte 
leakage level in lettuce by an average decrease of $15.7 \%$. The reduction of MDA level suggesting that the plant tissues of lettuce had the ability to maintain their membranes integrity.

Table 3. Changes in hydrogen peroxide $\left(\mathrm{H}_{2} \mathrm{O}_{2}\right)$, electrolyte leakage (EL) and malondialdehyde (MDA) contents in lettuce plant grown under silique EtOAc extract of $C$. arabica and its identified compounds at $50 \mu \mathrm{g} \mathrm{mL}{ }^{-1}$.

\begin{tabular}{|c|c|c|c|c|}
\hline & & $\begin{array}{l}\text { EL } \\
(\%)\end{array}$ & $\begin{array}{c}\text { MDA } \\
\left.\text { (nmol } \mathrm{g}^{-1} \mathrm{FW}\right)\end{array}$ & $\begin{array}{c}\mathrm{H}_{2} \mathrm{O}_{2} \\
\left(\mathrm{nmol} \mathrm{g}^{-1} \mathrm{FW}\right)\end{array}$ \\
\hline \multirow{9}{*}{ 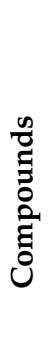 } & Control & $150.6 \pm 2.6^{b}$ & $50.3 \pm 2.3^{a}$ & $4.6 \pm 1.5^{\mathrm{a}}$ \\
\hline & EtOAc & $177.3 \pm 5.1 b^{c}$ & $64.2 \pm 1.9^{b}$ & $12.4 \pm 2.1^{b}$ \\
\hline & 1 & $210.6 \pm 3.9^{c}$ & $70.2 \pm 4.5^{c}$ & $15.3 \pm 2.6^{c}$ \\
\hline & 2 & $170.3 \pm 1.6 b^{c}$ & $62.3 \pm 2.4^{b}$ & $10.2 \pm 2.4^{b}$ \\
\hline & 3 & $201.6 \pm 2.5^{c}$ & $71.6 \pm 2.1^{\mathrm{c}}$ & $14.9 \pm 3.4^{c}$ \\
\hline & 4 & $183.7 \pm 2.6 b^{c}$ & $64.7 \pm 3.7^{b}$ & $12.3 \pm 1.9^{b}$ \\
\hline & 5 & $200.9 \pm 3.1^{c}$ & $72.6 \pm 5.9^{c}$ & $15.1 \pm 0.6^{c}$ \\
\hline & 6 & $124.3 \pm 0.9^{a}$ & $43.1 \pm 3.1^{\mathrm{a}}$ & $5.2 \pm 0.5^{\mathrm{a}}$ \\
\hline & 7 & $154.9 \pm 1.3^{b}$ & $54.3 \pm 7.3^{a}$ & $6.1 \pm 0.5^{a}$ \\
\hline
\end{tabular}

Note: The same letter indicates no significant differences $p<0.05$ (LSD test).

\subsubsection{Hydrogen Peroxide $\left(\mathrm{H}_{2} \mathrm{O}_{2}\right)$ Content}

According to our previous studied $[3,14]$ we have speculated that the inhibitory effect of the C. arabica extracts could be mediated induction of oxidative stress and ROS generation in target species. To address this possibility, we next determined the extent of ROS generation quantitatively in terms of hydrogen peroxide content in lettuce plant under C. arabica extract and its identified compounds. Overall, the results showed a great sensitivity of lettuce cell membranes to allelochemicals stress present in C. arabica extract compared to control. As shown in Table 3, among the treatments, the compounds $\mathbf{1}$, 3 , and 5 raised the $\mathrm{H}_{2} \mathrm{O}_{2}$ content in lettuce by an average increase of 3.28-fold. The other treatments enhanced the $\mathrm{H}_{2} \mathrm{O}_{2}$ content in lettuce by an average level of $11.63 \mathrm{nmoL} \mathrm{g}^{-1} \mathrm{FW}$, with the exception of the compounds 6 and 7, which they induced the lowest accumulation of $\mathrm{H}_{2} \mathrm{O}_{2}$ by an average level of $5.65 \mathrm{nmoL} \mathrm{g}^{-1} \mathrm{FW}$ compared to the control $4.6 \mathrm{nmol} \mathrm{g}^{-1} \mathrm{FW}$.

The measurement of the oxidative markers (increment of MDA and $\mathrm{H}_{2} \mathrm{O}_{2}$ level) of treated lettuce showed that our extract and its identified compounds cause an oxidative stress that could initiate a sequence of reactions inducing damages in cellular organelles, ultimately leading to cell death [29]. Among all the tested compounds, the electrolyte leakage, the MDA and the $\mathrm{H}_{2} \mathrm{O}_{2}$ level were significantly increased in lettuce plant where they reached the maximum by the compounds $\mathbf{1}$, 3 , and 5 resulting in disruption of membrane integrity. It was noted previously that the membrane functions and lipid stability were have deleterious effects on plants, and some natural products acts by interfering with the integrity of membranes, which can be evaluated by relative electrolyte leakage and MDA production. A decrease in membrane permeability could be due to peroxidation of polyunsaturated fatty acids in the membranes resulting in the formation of several by products, including malondialdehyde (MDA) [30]. Many studies have shown that membrane perturbations are often suggested the primary site of action of many allelochemicals that trigger further modifications in physiological processes of plant cell. At cellular level, it induces lipid peroxidation, affects some enzymatic activities and rapidly depolarizes the root cell membrane thereby increasing the membrane permeability, thus blocking plant nutrients uptake [31]. Moreover, the high production of $\mathrm{H}_{2} \mathrm{O}_{2}$ could interfere with the activity of enzymes, and therefore inhibit photosynthetic activity [32]. In the present study, the compounds from C. arabica induced an accumulation of $\mathrm{H}_{2} \mathrm{O}_{2}$ in lettuce that could be an important factor that regulates the occurrence of phytotoxicity in target species. Although evidence about allelochemical-induced oxidative stress together with increased activity of antioxidant enzymes is emerging $[33,34]$, but, little information is available about the mechanisms by which allelochemicals induce the oxidative damage. To date, the mode of action of $C$. arabica and its identified allelochemicals 
have remained elusive. Several action modes of different identified allelochemicals from other species have been previously suggested, including direct inhibition of photosynthesis process and ion uptake, interruption of dark respiration, and ATP synthesis and ROS-mediated allelopathic mechanisms [35]. According to the previous study [36,37], some identified flavonoids could inhibit electron transport in Photosystem II (PSII) and reduce the enzymatic activity of plastoquinone. Thus, the high bioactivity of the identified compound from C. arabica can be linked to their ability to interact with membranes. To determine if this phytotoxic effect occurs through oxidative stress, we continue analyzing the activity of some antioxidant enzymes involved in the detoxification and balance of $\mathrm{H}_{2} \mathrm{O}_{2}$ level, as well as membrane damage.

\subsection{Activation of Antioxidant Defensive Enzymes in Lettuce}

Plants respond to oxidative stress and ROS generation via the rapid stimulation of enzymatic antioxidant defense components. In this study, the antioxidant enzyme activities, including SOD, CAT and APX, were significantly increased in lettuce seedlings under the identified allelochemicals from C. arabica compared to untreated seedlings (Figure 5). These enzymes were more prominently influenced by compound 1 than the other treatments, and thus were consistent with their phytotoxic potential.
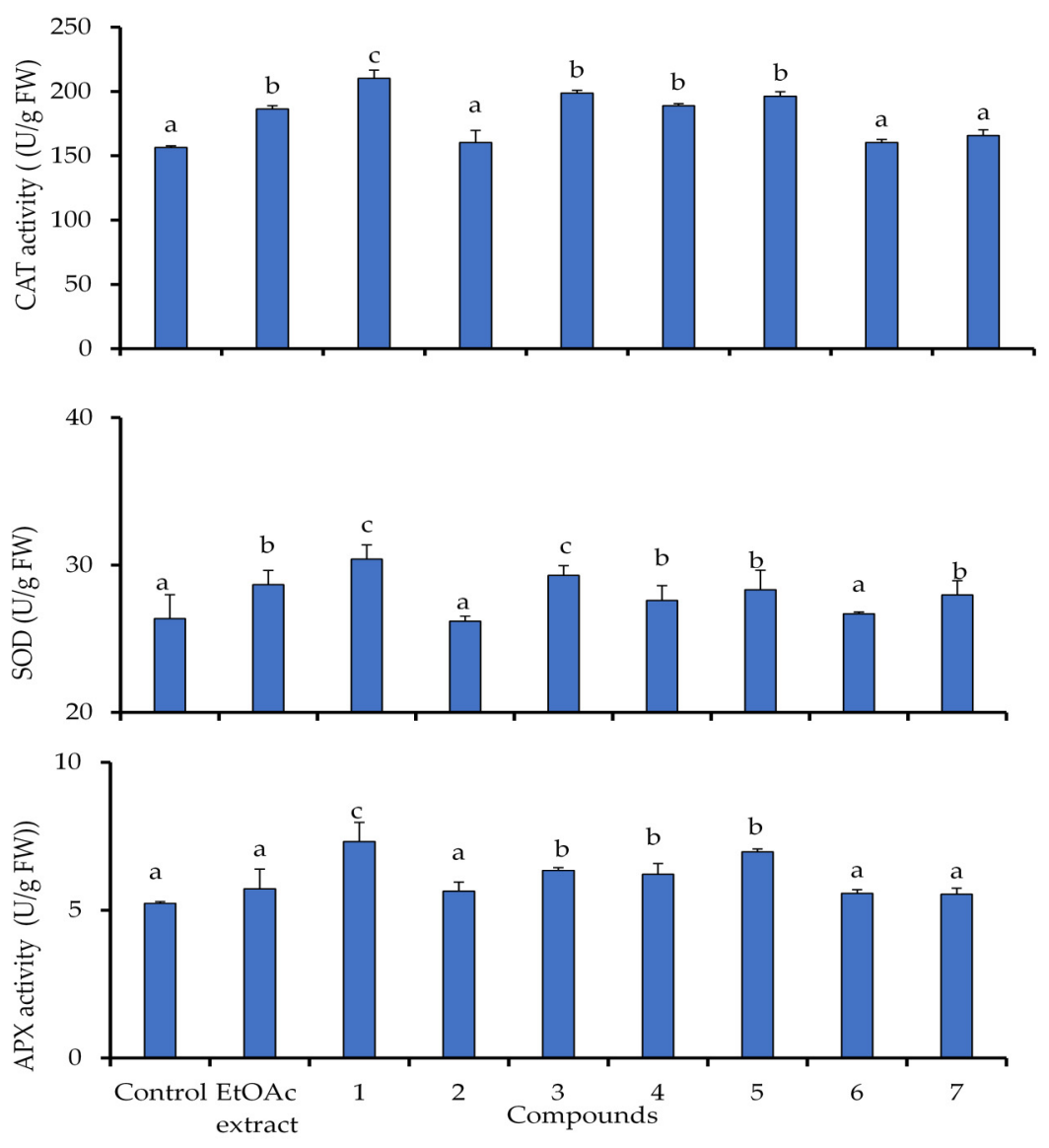

Figure 5. Superoxide dismutase (SOD), catalase (CAT), and ascorbate peroxidase (APX), activities in lettuce plants exposed to EtOAc extract of C. arabica and its identified compounds (1-7) at $50 \mu \mathrm{g} \mathrm{mL}^{-1}$. Values $(N=3 \pm$ S.E.). Different letters in columns indicate significant differences among treatments at $p<0.05$ (LSD test).

The activity of catalase (CAT) was increased in lettuce by $34.3 \%$ under the treatment of compound $\mathbf{1}$, while the other compounds induced an average stimulation of $23.1 \%$, except for the compounds 2,6 and 7 which they revealed the lowest stimulation of $6 \%$. Similarly, superoxide dismutase (SOD) was 
induced by a slight stimulation of $15.2 \%$ under compound 1, but this increase did not exceed $11.1 \%$ under the other treatments. The activities of ascorbate peroxidase (APX) was enhanced by $36.6 \%$ in lettuce seedlings under the compounds 1 and 5 . The induced stress response by compounds 3 and 4 was also depicted in lettuce by an average stimulation of $20 \%$, as well as lesser activation was revealed by $7.4 \%$ under the other treatments (Figure 5 ).

Generally, the excessive production of antioxidant enzymes in treated plant under allelochemicals stress have evolved the lettuce a complex system of enzymatic antioxidant in order to reduce the induced oxidative. From our study, the compound 1 improved the antioxidant activity by increasing the enzymes compared to the other treatments. Stimulation of antioxidant activity is commonly associated with enhanced stress tolerance in plants. The activation of the antioxidant enzymes under allelochemical stress have been proved previously in other plant species [38,39]. Moreover, Allelochemical compounds can also cause oxidative damage and activate antioxidant mechanisms [40,41]. Our results are in accordance with the previous studies, some identified allelochemicals activated the CAT activity in maize seedlings [42], and cucumber cotyledons [43]. In addition, the enhanced activity of SOD indicated that excessive generation of $\mathrm{O}_{2}{ }^{\bullet-}$ has been triggered by allelochemicals, which was then upregulated to mitigate the oxidative damage. However, these results disagree with other findings, which they have described the reduction of SOD activity in seeds of rape, cucumber, corn, sorghum [44] and lettuce under allelochemical stress [45].

\subsection{Correlation between Phytotoxic Potential and Antioxidant Parameters}

The detailed relationships between the physiological parameters, the oxidative stress markers and antioxidant enzymes defense system in lettuce plant treated with EtOAc extract and its identified compounds (Table 4). The results exposed strong positive correlation between growth parameters (RL and SL) and germination index that could demonstrate the strong inhibitory effect of the compounds. This inhibitory effect as explained by the great positive correlation between the MI and growth parameters, which was highly correlated with RL $(r=0.92, p<0.01)$. However, the MI was negatively correlated with the oxidative stress markers and the antioxidant enzymes. It was noted that the oxidative stress markers (EL, MDA and $\mathrm{H}_{2} \mathrm{O}_{2}$ ) was positively correlated with antioxidant enzymes and was markedly positively correlated between $\mathrm{H}_{2} \mathrm{O}_{2}$ and CAT $(r=0.92, p<0.01)$. According to Sánchez-Moreiras et al. [27], the negative effects on plant growth was highly correlated with a drastic inhibition of the mitotic activity. It has been demonstrated also that electrolyte leakage measurements may be correlated with several physiological and biochemical parameters conditioning the plant responses to environmental conditions [46].

Table 4. Pearson correlations between analyzed phytotoxic parameters, oxidative stress markers and antioxidant enzymes responses of lettuce plants to allelochemical stress of $C$. arabica.

\begin{tabular}{|c|c|c|c|c|c|c|c|c|c|c|}
\hline & GI & RL & SL & MI & EL & MDA & $\mathrm{H}_{2} \mathrm{O}_{2}$ & CAT & SOD & APX \\
\hline IG & & & & & & & & & & \\
\hline RL & $0.920 * *$ & & & & & & & & & \\
\hline SL & $0.929^{* *}$ & $0.947^{* *}$ & & & & & & & & \\
\hline MI & $0.699 *$ & $0.924^{* *}$ & $0.843^{* *}$ & & & & & & & \\
\hline EL & 0.433 & 0.631 & 0.494 & $-0.880^{* *}$ & & & & & & \\
\hline MDA & 0.322 & 0.528 & 0.377 & $-0.874^{* *}$ & $0.978^{* *}$ & & & & & \\
\hline $\mathrm{H}_{2} \mathrm{O}_{2}$ & 0.282 & 0.471 & 0.304 & $-0.951^{* *}$ & $0.947^{* *}$ & $0.962^{* *}$ & & & & \\
\hline CAT & 0.349 & 0.555 & 0.429 & $-0.946^{* *}$ & 0.900 ** & $0.854^{* *}$ & $0.922 * *$ & & & \\
\hline SOD & 0.267 & 0.464 & 0.374 & $-0.813^{* *}$ & $0.765 *$ & $0.690 *$ & $0.747^{*}$ & $0.907^{* *}$ & & \\
\hline APX & 0.514 & 0.570 & 0.518 & $-0.934^{* *}$ & $0.842 * *$ & 0.781 * & $0.847^{* *}$ & $0.905^{* *}$ & $0.755^{*}$ & \\
\hline
\end{tabular}

Notes: GI, germination index; RL, root length; SL, shoot length; MI, Mitotic Index; El, Electrolyte Leakage; MDA, lipid peroxidation; $\mathrm{H}_{2} \mathrm{O}_{2}$, hydrogen peroxide; CAT, Catalase; SOD, superoxide dismutase; APX, ascorbate peroxidase. ${ }^{* *}$ Correlation is significant at the 0.01 level. * Correlation is significant at the 0.05 level. 


\subsection{Cluster and Principal Compound Analysis}

Cluster analysis (CA) was conducted based on the physiological and antioxidant enzymes activities of the identified compounds from C. arabica silique EtOAc extract (Figure 6). This analysis revealed that the compounds are grouped into three clusters. This indicates that the identified compounds have different behavior based on the phytotoxic effect and antioxidant defense system in lettuce plant. It can also be seen that the compounds $\mathbf{1}$ and $\mathbf{5}$ are grouped in which are the most active compounds, while the lowest activities was exhibited by the third cluster grouping the compounds 2,6 , and $\mathbf{7}$. The medium activities was recorded similar by the compounds 3, 4, and EtOAc extract which are clustered by the second group. This grouping gives indication that identified compounds in each group have different characteristics conducting to dissimilar effects among them.

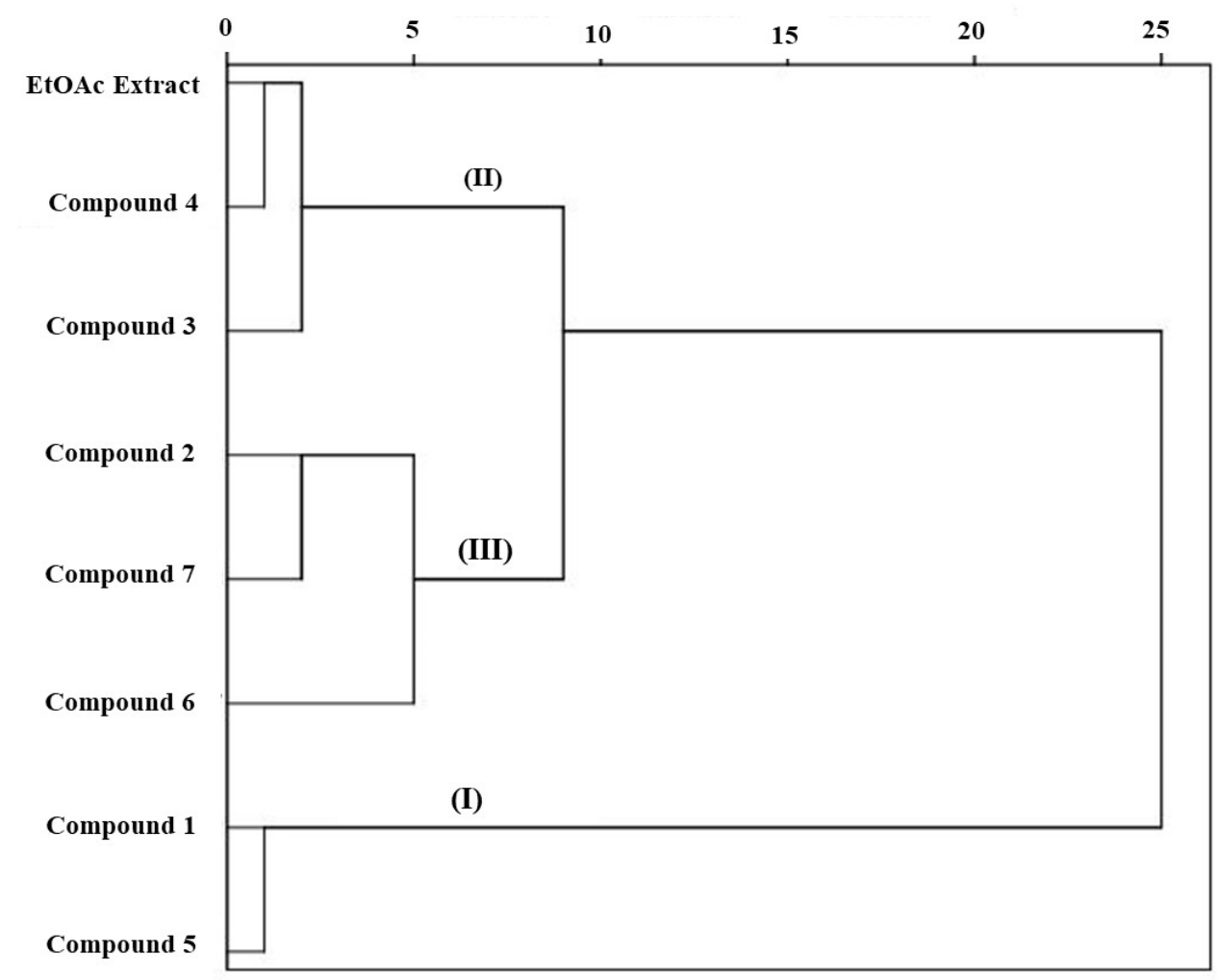

Figure 6. Cluster analysis of EtOAc extract of C. arabica silique and its identified compounds (1-7) based on their phytotoxic and antioxidant responses of lettuce plant.

To obtain a more comprehensive understanding of the physiological responses of lettuce to different compounds, the results of PCA were presented by a biplot (Figure 7). The first two principal components explained $65.11 \%$ and $30.75 \%$ of the data variability, respectively. Almost all physiological and antioxidant parameters, including MDA, EL, $\mathrm{H}_{2} \mathrm{O}_{2}, \mathrm{SOD}$, and $\mathrm{CAT}$, were positively related to PC1, while the APX were negatively related to PC1. While, the MI was positively related to PC2. The compounds 1 and $\mathbf{5}$ exhibited great phytotoxic and antioxidant effects with an important damage in membrane integrity. It was noted that the EtOAc extract and the compound 4 are characterized by the same effects. However, the compounds 2, 6, and 7 have the weakest effect compared to the other treatments. While, the control MI has the greatest values compared to the other treatments (Figure 7). 


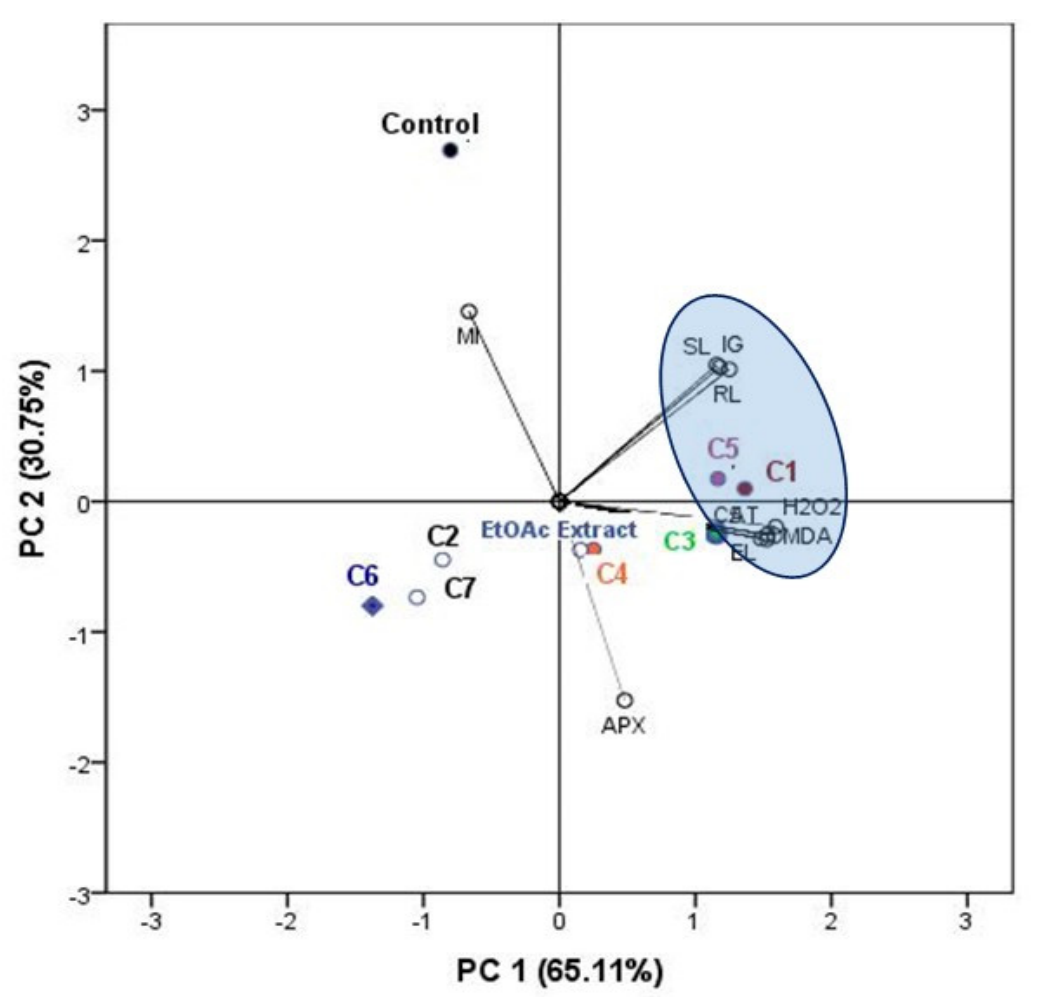

Figure 7. Biplot of the principal components analysis (PCA) based on the phytotoxic and antioxidant responses of lettuce plant to EtOAc extract of $C$. arabica silique and its identified compounds (1-7).

\section{Materials and Methods}

\subsection{Plant Material}

C. arabica was collected from the South-West of Tunisia (latitude $34^{\circ} 25^{\prime} \mathrm{N}$; longitude $8^{\circ} 46^{\prime} \mathrm{E}$ ). The plant was identified according to Tunisia flora [47] and authenticated by Dr. Afef Ladhari. A voucher specimen was dried and deposited in the herbarium of the university of Carthage, Tunisia.

\subsection{Isolation and Identification of Bioactive Compound}

\subsubsection{General Experimental Procedures}

${ }^{1} \mathrm{H}$ and ${ }^{13} \mathrm{C}$ NMR spectra were run on a Varian INOVA $500 \mathrm{NMR}$ spectrometer at 500 and $125 \mathrm{MHz}$, respectively, in $\mathrm{CDCl}_{3}$ or $\mathrm{CD}_{3} \mathrm{OD}$ at $25{ }^{\circ} \mathrm{C}$. UV-Vis spectra were recorded with a Varian Cary 300 UV-Vis spectrophotometer. LC-MS analyses were run on an Agilent LC-MS ESI-TOF 1260/6230DA instrument operating in positive ionization mode. Flash column chromatography was performed on Merck Kieselgel 60 (230-400 mesh) at a medium pressure. Column chromatography (CC) was performed on Merck Kieselgel 60 (70-240 mesh), on Sephadex LH-20 (Pharmacia). Analytical TLC was performed on Merck Kieselgel 60 F254 or RP-18 F254 plates with $0.2 \mathrm{~mm}$ film thickness. Spots were visualized by UV light or by spraying with $\mathrm{EtOH}: \mathrm{H}_{2} \mathrm{SO}_{4}$ (93:7) followed by heating for $5 \mathrm{~min}$ at $110{ }^{\circ} \mathrm{C}$. Preparative TLC was performed on Merck Kieselgel 60 F254 plates, with 0.5 or $1 \mathrm{~mm}$ film thickness. HPLC purifications were carried out on an Agilent 1100 HPLC system, equipped with an UV detector set at $280 \mathrm{~nm}$.

\subsubsection{Extraction and Isolation}

Dried powder $(1.5 \mathrm{~kg})$ of silique of $C$. arabica was extracted twice at room temperature with $\mathrm{MeOH}$ during $48 \mathrm{~h}$. After filtering, extracts were combined and dried at reduced pressure; the obtained residues were re-dissolved in $\mathrm{MeOH}: \mathrm{H}_{2} \mathrm{O}$ (1:1) defatted with petroleum ether and extracted three 
times with ethyl acetate. Crude extract was dried with $\mathrm{Na}_{2} \mathrm{SO}_{4}$ and evaporated under reduced pressure originating a brown oil residue $(97.3 \mathrm{~g})$ that was purified by silica gel column chromatography (CC) using $\mathrm{CH}_{2} \mathrm{Cl}_{2} \rightarrow$ EtOAc $\rightarrow \mathrm{MeOH} \rightarrow \mathrm{CH}_{2} \mathrm{Cl}_{2}$ (2:1) $\rightarrow \mathrm{MeOH}$ as eluents, to give 23 homogeneous fractions (AC1-AC23). Fraction AC9 (500.2 mg), eluted with $\mathrm{MeOH}: \mathrm{CH}_{2} \mathrm{Cl}_{2}$ (2:1), was again purified on Sephadex LH-20 (CC) eluted with: $n$-hexane: $\mathrm{CH}_{2} \mathrm{Cl}_{2}: \mathrm{MeOH}(7: 4: 0.5 \rightarrow 6: 4: 1) \rightarrow \mathrm{MeOH}$, to give 16 homogeneous fractions (AC9-1_AC9-16). AC9 6 fraction was further purified by preparative TLC (1 mm) on silica gel eluted with $\mathrm{CH}_{2} \mathrm{Cl}_{2}: \mathrm{MeOH}$ (9:1) obtained compound $5(30.5 \mathrm{mg})$. The fraction AC9-13 (12.8 mg) was subjected to RP-18 HPLC with a mobile phase of MeCN:MeOH: $\mathrm{H}_{2} \mathrm{O}$ (4:5:1) to yield compound $1(9.2 \mathrm{mg})$. Fraction AC17 (600.9 mg) of first CC was chromatographed by Sephadex LH-20 $\mathrm{CC}\left(\mathrm{MeOH} \rightarrow \mathrm{MeOH}: \mathrm{H}_{2} \mathrm{O}(8: 2)\right)$ to give 2 fractions: $\mathrm{AC} 17_{-\mathrm{A}}(100.8 \mathrm{mg})$ and $\mathrm{AC}_{-\mathrm{B}}(450.6 \mathrm{mg})$. The fraction eluted with $\mathrm{MeOH}\left(\mathrm{AC} 17_{-\mathrm{A}}\right.$ ) was further purified on Sephadex $\mathrm{LH}-20 \mathrm{CC}\left(\mathrm{MeOH}: \mathrm{H}_{2} \mathrm{O}(8: 2)\right.$ ) to give 18 fractions (AC17-A1-18). The fraction AC17-A12 was purified by RP-18 HPLC with a mobile phase $\mathrm{MeCN}: \mathrm{MeOH}: \mathrm{H}_{2} \mathrm{O}$ (3:6:1) to obtain the compound 3 (9.7 mg). AC17 $-\mathrm{B}$ was purified on Sephadex LH-20 CC with MeOH: $\mathrm{H}_{2} \mathrm{O}$ (8:2) as eluent, given 9 fractions (AC17-B1-9). AC17-B-6 was again purified on Sep-Pak C-18 eluted with $\mathrm{H}_{2} \mathrm{O} \rightarrow \mathrm{MeOH}(1: 1) \rightarrow \mathrm{MeOH}$ to yield compound 4 (10 mg). The fraction AC4 $(668.3 \mathrm{mg})$ of first $\mathrm{CC}$, was further fractionated by flash column chromatography on silica gel eluted with EtOAc: $\mathrm{CH}_{2} \mathrm{Cl}_{2}(1: 9 \rightarrow 1: 4 \rightarrow 3: 7) \rightarrow \mathrm{MeOH}$ to yield 10 homogeneous fractions (AC4A-J). The fraction AC4A (350.6 mg) was next fractionated by flash column chromatography on silica gel eluted with EtOAc: $\mathrm{CH}_{2} \mathrm{Cl}_{2}(1: 9 \rightarrow 1: 4 \rightarrow 3: 7) \rightarrow$ EtOAc $\rightarrow$ MeOH: EtOAc $(1: 9) \rightarrow \mathrm{MeOH}$ to get 17 fractions $\left(\mathrm{AC} 4_{\mathrm{A}-1-17}\right)$. The fraction AC4 $4_{\mathrm{A}-8}$ eluted with EtOAc: $\mathrm{CH}_{2} \mathrm{Cl}_{2}$ (1:4) was subjected to RP-18 HPLC with $\mathrm{CH}_{3} \mathrm{CN}: \mathrm{MeOH}: \mathrm{H}_{2} \mathrm{O}$ (2:5:3) as mobile phase to obtain the compound 2. Finally, AC4E (18 mg) was purified by RP-18 HPLC $\left(\mathrm{CH}_{3} \mathrm{CN}: \mathrm{MeOH}: \mathrm{H}_{2} \mathrm{O}(2: 5: 3)\right)$ to obtain compounds 6 and 7.

\subsection{Phytotoxic Assays}

The phytotoxic activity was achieved through the assessment of the ethyl acetate extract from C. arabica silique and its identified compounds on the germination and seedling growth of $L$. sativa. The seeds were surface sterilized with sodium hypochlorite solution $(0.4 \%, v / v)$ for $3 \mathrm{~min}$ and soaked in sterile distilled water for $30 \mathrm{~min}$. Twenty seeds were sown in Petri dishes containing layers of Whatman filter paper, impregnated with $5 \mathrm{~mL}$ of distilled water (control) or $5 \mathrm{~mL}$ of tested solution. The ethyl acetate extract and its identified compounds were diluted with methanol to the desired concentrations (50, 100, 200, 400, $\left.800 \mu \mathrm{g} \mathrm{mL}^{-1}\right)$. Two sets of Petri plates were prepared. In the first set, imbibed seeds were used to evaluate the effect of extracts on germination. The second set of pre-germinated seeds with $1 \mathrm{~mm}$ root length, was used to evaluate the effect of the extract and its isolated compounds on root and shoot lengths. The Petri dishes were placed in a growth chamber at $24 / 22{ }^{\circ} \mathrm{C}$ for $14 / 10 \mathrm{~h} \mathrm{light}$ and dark periods, respectively. Germination was determined by counting the number of seeds that had germinated at $24 \mathrm{~h}$ intervals over 6 days. Shoot and root lengths were measured 7 days after placing the pre-germinated seeds in each Petri dish. Data were transformed to percent of control for analysis. The index of germination (GI) and the \% inhibition/stimulation were calculated according to Chiapuso et al. [48] and Chung et al. [49], respectively.

\subsection{Cytogenotoxicity Test}

The cytogenotoxicity assays of $C$. arabica ethyl acetate extract and its identified compounds were assessed by the same environmental conditions as those previously described. Root tips were collected $24 \mathrm{~h}$ after the start of the experiment, when the newly emerged roots reached $1.50-2.00 \mathrm{~cm}$ in length, they were used. The newly emerged roots were treated by the lowest concentration of the acetate extract and the identified compounds at $50 \mu \mathrm{g} \mathrm{mL} \mathrm{L}^{-1}$ for $48 \mathrm{~h}$. To avoid toxic effect of solvents, the filter papers were placed in a fume hood for $30 \mathrm{~min}$ to allow complete solvent evaporation. Subsequently, $5 \mathrm{~mL}$ of distilled water were added to each Petri dish. The control group was treated with distilled water. At the end of each exposure period, root tips were cut and subsequently fixed in Carnoy's solution (absolute ethanol/glacial acetic acid $(3: 1, v / v)$ ) for $24 \mathrm{~h}$ and stored at $-18^{\circ} \mathrm{C}$. The cytological 
preparations were made using the method described previously by Koodkaew et al. [50] with some modifications. Staining of the chromosome was carried out with acetic carmine for $30 \mathrm{~min}$. One $\mathrm{mm}$ of the meristematic zone was immersed in a drop of $45 \%$ acetic acid on a clean slide and squashed under a cover slip by thumb pressure. For each treatment, 1000 cells were evaluated to determine the mitotic index (MI). The mitotic index (MI) was calculated as the proportion of dividing cells (M phase) to the total number of cells observed. The frequency of each mitotic phase was calculated as the percentage in relation to the number of cells in mitosis in the treatment.

\subsection{Oxidative Stress Response of Lettuce to C. arabica Extract and Its Identified Active Compounds}

The Oxidative stress markers and the antioxidant enzyme activity of $C$. arabica ethyl acetate extract and its identified compounds were investigated on lettuce at the lowest concentration of $50 \mu \mathrm{g} \mathrm{mL}{ }^{-1}$. The seeds of lettuce were grown for 10 days under the same conditions described for the previous phytotoxic assays, in order to obtain the biomass needed for extraction.

\subsubsection{Determination of Electrolyte Leakage (EL)}

According to Shalata and Neumann [51] the electrolyte leakage (EL) was estimated. The control and treated fresh lettuce were homogenized in tubes containing $25 \mathrm{~mL}$ of distilled water at room temperature in dark. After $24 \mathrm{~h}$, the initial bathing solution electrical conductivity (L1), where the samples were immersed, was measured using a digital conductivity meter (type BCT-4308). The samples were then autoclaved at $121^{\circ} \mathrm{C}$ for $20 \mathrm{~min}$ in order to burst cell walls and liberate all electrolytes, and then cooled down to $25^{\circ} \mathrm{C}$, there after incubated again in distilled water as indicated previously. After 24 h, a last conductivity reading (L2) was obtained. The electrolyte leakage (EL) was defined as follows:

$$
\mathrm{EL}(\%)=(\mathrm{L} 1 / \mathrm{L} 2) \times 100 .
$$

\subsubsection{Lipid Peroxidation}

The malondialdehyde (MDA) is produced during lipid peroxidation and can be used as a marker of oxidative stress. Its concentration in the whole lettuce plant was measured three days after the treatments [52]. The samples of $250 \mathrm{mg}$ were homogenized with a mortar and pestle in $2.5 \mathrm{~mL}$ of a mixture containing phosphate buffer $67 \mathrm{mM}$ and $500 \mathrm{mg}$ of PVP (polyvinylpyrrolidone). The mixture was centrifuged at $2000 \mathrm{rpm}$ for $15 \mathrm{~min}$ at $4{ }^{\circ} \mathrm{C}$. An assay mixture containing $2 \mathrm{~mL}$ of the supernatant and $2 \mathrm{~mL}$ of $0.5 \%(w / v)$ thiobarbituric acid (TBA) in 20\% (w/v) trichloroacetic acid (TCA) was heated at $90{ }^{\circ} \mathrm{C}$ for $10 \mathrm{~min}$ and then rapidly cooled in an ice bath. After centrifugation $(2,000 \mathrm{~g}$ for $10 \mathrm{~min}$ at $\left.4{ }^{\circ} \mathrm{C}\right)$, the supernatant absorbance was recorded at $532 \mathrm{~nm}$ and corrected for non-specific absorbance at $600 \mathrm{~nm}$. Lipid peroxidation products were measured as the content of TBA-reactive substances. Its content (nmol g${ }^{-1}$ ) was calculated according to the molar extinction coefficient of $155 \mathrm{mM}^{-1} \mathrm{~cm}^{-1}$.

\subsubsection{Determination of Hydrogen Peroxide $\left(\mathrm{H}_{2} \mathrm{O}_{2}\right)$ Content}

Hydrogen peroxide $\left(\mathrm{H}_{2} \mathrm{O}_{2}\right)$ is produced during oxidative stress. Its content in the lettuce plants was determined using the protocol described by Velikova et al. [53]. Treated plants were extracted with trichloroacetic acid $\mathrm{mL}$ of $0.1 \%$ TCA in an ice bath, and centrifuged at 12,000 rpm for $15 \mathrm{~min}$. Then, $0.5 \mathrm{~mL}$ of supernatant was mixed with $0.5 \mathrm{~mL}$ phosphate buffer ( $\mathrm{pH} 7)$ and $1 \mathrm{~mL}$ of potassium iodide $(1 \mathrm{M})$. The absorbance of this reaction mixture was measured at $390 \mathrm{~nm}$. Hydrogen peroxide content was determined using the extinction coefficient $0.28 \mu \mathrm{M}^{-1} \mathrm{~cm}^{-1}$ and expressed as nmol $\mathrm{g}^{-1}$.

\subsection{Antioxidant Enzyme Activities}

To extract antioxidant enzymes, whole lettuce plant $(200 \mathrm{mg}$ ) (from each treatment or control) was homogenized in $10 \mathrm{~mL}$ of sodium phosphate buffer $(0.1 \mathrm{M}, \mathrm{pH}$ 7.0). The homogenized material was centrifuged at $13,000 \mathrm{rpm}$ for $30 \mathrm{~min}$ at $4{ }^{\circ} \mathrm{C}$, and the supernatant was collected for the enzymatic 
analyses of superoxide dismutase (SOD), catalase (CAT), and ascorbate peroxidase (APX), which was quantified from spectrophotometer readings. The final volume of the reaction for reading enzyme activity was $2 \mathrm{~mL}$. All readings were conducted in triplicate.

Superoxide dismutase was assayed according to the following method proposed by Giannopolitis and Ries [54]. The absorbance was determined at $560 \mathrm{~nm}$ and one unit of SOD activity defined as the quantity of the enzyme that inhibits nitro-blue tetrazolium (NBT) photoreduction by $50 \%$. Catalase activity was measured as per the method of Cakmak and Marschner [55]. The reaction mixture $(2 \mathrm{~mL})$ consisted of $25 \mathrm{mM}$ phosphate buffer ( $\mathrm{pH} 7.0$ ), $10 \mathrm{mM} \mathrm{H}_{2} \mathrm{O}_{2}$ and $0.2 \mathrm{~mL}$ of enzyme extract. The activity was determined by measuring the rate of disappearance of $\mathrm{H}_{2} \mathrm{O}_{2}$ for $1 \mathrm{~min}$ at $240 \mathrm{~nm}$ and calculated using an extinction coefficient of $39.4 \mathrm{mM}^{-1} \mathrm{~cm}^{-1}$ and expressed as enzyme units $\mathrm{g}^{-1} \mathrm{FW}$. One unit of CAT activity was defined as the amount of enzyme that catalyzes decomposition of $1 \mu \mathrm{M} \mathrm{min}{ }^{-1}$ of $\mathrm{H}_{2} \mathrm{O}_{2}$. The ascorbate reductase activity was quantified according to the following method proposed by Nakano and Asada [56] using an extinction coefficient of $2.8 \mathrm{mM}^{-1} \mathrm{~cm}^{-1}$ by measuring the decrease in absorbance at $290 \mathrm{~nm}$ for $1 \mathrm{~min}$. It was expressed as enzyme units $\mathrm{g}^{-1} \mathrm{FW}$. One enzyme unit was defined as the amount of enzyme required to oxidize $1 \mu \mathrm{M}$ of ascorbate $\mathrm{min}^{-1}$.

\subsection{Statistical Analyses}

The laboratory bioassays in a complete randomized design with three replications were performed using IBM SPSS Statistics 20.0, to evaluate the effects of $C$. arabica extracts and its identified compounds over the control values. Experimental data were subjected to one-way analysis of variance (ANOVA) and a post hoc LSD tests, to determine significance differences among mean values at the probability level of 0.05 . The data obtained for all parameters in accordance with all tested methanol extracts were subjected to principal components analysis (PCA) and hierarchical cluster analysis (HCA) using SPSS 20.0 software.

\section{Conclusions}

This is the first report on the mode of action of the identified allelochemicals from the silique of $C$. arabica. The allelochemical action was mainly evident from the lowest concentration of $50 \mu \mathrm{g} \mathrm{mL}^{-1}$, which interfered with the initial growth of L. sativa seedlings. Cleomoside A was responsible for the most phytotoxic effect, promoting a drastic reduction in root, and shoot lengths, as well as frequency of germinated seeds. This compound influenced the cell cycle by reducing the mitotic index, indicating its cytotoxicity. Furthermore, the phytotoxic effects of $C$. arabica based compounds are positively and negatively correlated with oxidative markers and plant antioxidant enzymes (SOD, APX, and CAT) respectively, which contribute to the defence mechanism. The physiological and cytological changes caused by the identified compound, described here, help to get an insight into the detailed mode of action of allelochemical such as flavonoids, triterpene and thiohydroximate. This study provides the first information about the possible exploitation of the identified compounds from C. arabica, especially cleomoside A: A thiohydroximate, as a new bioherbicide, since it probably acts by inhibiting or disturbing cell division.

Supplementary Materials: The following are available online, Figure S1: ${ }^{1} \mathrm{H}$ NMR spectrum compound 1, Figure S2: ${ }^{13} \mathrm{C}$ NMR spectrum compound 1, Figure S3: COSY spectrum compound 1, Figure S4: HSQC spectrum compound 1, Figure S5: HMBC spectrum compound 1, Figure S6: DEPT spectrum compound 1, Figure S7: Mass spectrum compound 1 .

Author Contributions: A.L. and M.D. performed the laboratory experiments and drafted the manuscript; A.A. contributed to the analysis of chemical data of the experiments. All authors have read and agreed to the published version of the manuscript.

Funding: This research received no external funding.

Conflicts of Interest: The authors declare no conflict of interest. 


\section{References}

1. Van Evert, F.K.; Fountas, S.; Jakovetic, D.; Crnojevic, V.; Travlos, I.; Kempenaar, C. Big data for weed control and crop protection. Weed Res. 2017, 57, 218-233. [CrossRef]

2. Dayan, F.E.; Duke, S.O. Discovery for new herbicide sites of action by quantification of plant primary metabolite and enzyme pools. Engineering 2020, 6, 509-514. [CrossRef]

3. Ladhari, A.; Omezzine, F.; DellaGreca, M.; Zarrelli, A.; Zuppolini, S.; Haouala, R. Phytotoxic activity of Cleome arabica L. and its principal discovered active compounds. S. Afr. J. Bot. 2013, 88, 341-351. [CrossRef]

4. Macías, F.A.; Oliveros-Bastidas, A.; Marín, D.; Chinchilla, N.; Castellano, D.; Molinillo, J.M.G. Evidence for an allelopathic interaction between rye and wild oats. J. Agric. Food Chem. 2014, 62, 9450-9457. [CrossRef] [PubMed]

5. Takhi, D.; Ouinten, M.; Yousfi, M. Study of antimicrobial activity of secondary metabolites extracted from spontaneous plants from the area of Laghouat, Algeria. Adv. Environ. Biol. 2011, 5, 469-476.

6. Khalafallah, A.K.; Mohamed, A.H.; Yousof, A.H.; Hussien, T.A.; Mohamed-Elamir, F.H.; Shinji, O. Damarane triterpene from Cleome arabica. Pharmacogn. Res. 2009, 1, 162-165.

7. Ismail, S.I.; Ito, H.; Selloum, L.; Bouriche, H.; Yoshida, T. Constituents. of Cleome arabica leaves and twigs. Nat. Med. 2005, 59, 53.

8. Djeridane, A.; Yousfi, M.; Brunel, J.M.; Stocker, P. Isolation and characterization of a new steroid derivative as a powerful antioxidant from Cleome arabica in screening the in vitro antioxidant capacity of 18 Algerian medicinal plants. Food Chem. Toxicol. 2010, 48, 2599-2606. [CrossRef]

9. Bouriche, H.; Arnhold, J. Effect of Cleome arabica leaf extract treated by naringinase on human neutrophil chemotaxis. Nat. Prod. Commun. 2010, 5, 415-418. [CrossRef]

10. McDanell, R.; McLean, A.E.M.; Hanley, A.B.; Heaney, R.K.; Fenwick, G.R. Chemical and biological properties of indole glucosinolates (glucobrassicins): A review. Food Chem. Toxicol. 1988, 26, 59-70. [CrossRef]

11. Agerbirk, N.; Petersen, B.L.; Olsen, C.E.; Halkier, B.A.; Nielsen, J.N.J. 1,4-Dimethoxyglucobrassicin in Barbarea and 4-hydroxyglucobrassicin in Arabidopsis and Brassica. Agric. Food Chem. 2001, 49, 1502-1507. [CrossRef]

12. Das, S.; Tyagi, A.K.; Singhal, K.K. Effect of Glucosinolates of Taramira (Eruca Sativa) oil cake on nutrient utilization and growth of crossbred calves. Asian-Aust. J. Anim. Sci. 2003, 16, 813-817. [CrossRef]

13. Fahey, J.W.; Zalcmann, A.T.; Talalay, P. The chemical diversity and distribution of glucosinolates and isothiocyanates among plants. Phytochemistry 2001, 56, 5-51. [CrossRef]

14. Ladhari, A.; Omezzine, F.; Haouala, R. The impact of Tunisian Capparidaceae species on cytological, physiological and biochemical mechanisms in lettuce. S. Afr. J. Bot. 2014, 93, 222-230. [CrossRef]

15. Romero-Romero, T.; Sanchez-Nieto, S.; Sanjuan-Badillo, A.; Amaua, A.L.; Cruz-Ortega, R. Comparative effects of allelochemical and water stress in roots of Lycopersicon esculentum Mill. (Solanaceae). Plant Sci. 2005, 168, 1059-1066. [CrossRef]

16. DellaGreca, M.; Mancino, A.; Previtera, L.; Zarrelli, A.; Zuppolini, S. Lignans from Phillyrea angustifolia L. Phytochem. Lett. 2011, 4, 118-121. [CrossRef]

17. Ribeiro, A.; Pilo-Veloso, D. Trypanocidal flavanoids from Trixis vauthieri. J. Nat. Prod. 1997, 60, 836-838. [CrossRef]

18. Sharaf, M.; El-Ansari, M.A.; Saleh, N.A.M. Flavonoids of four cleome and three capparis species. Biochem. Syst. Ecol. 1997, 25, 161-166. [CrossRef]

19. Sekine, K.; Hase, T.; Sato, N. Reversible DNA compaction by sulfite reductase regulates transcriptional activity of chloroplast nucleoids. J. Biol. Chem. 2002, 277, 24399-24404. [CrossRef]

20. Taiz, L.; Zeiger, E. Plant Physiology, 5th ed.; Sinauer Associates: Sunderland, UK, 2010; p. 782.

21. Grubb, C.D.; Abel, S. Glucosinolate metabolism and its control. Trends Plant Sci. 2006, 11, 89-100. [CrossRef]

22. Moreland, D.E.; Novitski, W.P. Interference by flavone and flavonols with chloroplast-mediated electron transport and phosphorylation. Phytochemistry 1988, 27, 3359-3365. [CrossRef]

23. Stenlid, G. Flavonoids as inhibitors of the formation of adenosine triphosphate in plant mitochondria. Phytochemistry 1970, 9, 2251-2256. [CrossRef]

24. Blum, U. Plant-Plant Allelopathic Interactions: Partitioning and Seedling Effects of Phenolic Acids as Related to Their Physicochemical and Conditional Properties, 1st ed.; Springer: London, UK, 2014. [CrossRef] 
25. Rojas, E.; Herrera, L.A.; Sordo, M.; Gonsebatt, M.E.; Montero, R.; Rodriguez, R.; Ostrosky-Wegman, P. Mitotic index and cell proliferation kinetics for identification of antineoplastic activity. Anti-Cancer Drugs 1993, 4, 637-640. [CrossRef] [PubMed]

26. Hallak, A.M.G.; Davide, L.C.; Souza, I.F. Effects of sorghum (Sorghum bicolor L.) root exudates on the cell cycle of the bean plant (Phaseolus vulgaris L.) root. Genet. Mol. Biol. 1999, 22, 95-99. [CrossRef]

27. Sánchez-Moreiras, A.M.; De La Pena, T.C.; Reigosa, M.J. The natural compound benzoxazolin-2(3H)-one selectively retards cell cycle in lettuce root meristems. Phytochemistry 2008, 69, 2172-2179. [CrossRef]

28. Nishida, N.; Tamotsu, S.; Nagata, N.; Saito, C.; Sakai, A. Allelopathic effects of volatile monoterpenoids produced by Salvia leucophylla: Inhibition of cell proliferation and DNA synthesis in the root apical meristem of Brassica campestris seedlings. J. Chem. Ecol. 2005, 31, 1187-1203. [CrossRef] [PubMed]

29. Ribeiro, R.C.; Feitoza, R.B.B.; Lima, H.R.P.; De Carvalho, G.M. Phytotoxic effects of phenolic compounds on Calopogonium mucunoides (Fabaceae) roots. Aust. J. Bot. 2015, 63, 679-686. [CrossRef]

30. Maness, P.C.; Smolinski, S.; Blake, D.M.; Huang, Z.; Wolfrum, E.J.; Jacoby, W.A. Bactericidal activity of photocatalytic $\mathrm{TiO}_{2}$ reaction: Toward an understanding of its killing mechanism. Appl. Environ. Microbiol. 1999, 65, 4094-4098. [CrossRef] [PubMed]

31. Weir, T.L.; Park, S.W.; Vivanco, M. Biochemical and physiological mechanisms mediated by allelochemicals. Curr. Opin. Plant Biol. 2004, 7, 472-479. [CrossRef]

32. Harminder, P.; Batish, D.R.; Kaur, S.; Arora, K.; Kohli, R.K. $\alpha$-Pinene inhibits growth and induces oxidative stress in roots. Ann. Bot. 2006, 98, 1261-1269. [CrossRef]

33. Yu, J.Q.; Ye, S.F.; Zhang, M.F.; Hu, W.H. Effects of root exudates, aqueous root extracts of cucumber (Cucumis sativus L.) and allelochemicals on photosynthesis and antioxidant enzymes in cucumber. Biochem. Syst. Ecol. 2003, 31, 129-139. [CrossRef]

34. Ye, S.F.; Zhou, Y.H.; Sun, Y.; Zou, L.Y.; Yu, J.Q. Cinnamic acid causes oxidative stress in cucumber roots, and promotes incidence of Fusarium wilt. Environ. Exp. Bot. 2006, 56, 255-262. [CrossRef]

35. Inderjit; Duke, S.O. Ecophysiological aspects of allelopathy. Planta 2003, 217, 529-539. [CrossRef] [PubMed]

36. Tigre, R.C.; Pereira, E.C.; da Silva, N.H.; Vicente, C.; Legaz, M.E. Potential phenolic bioherbicides from Cladonia verticillaris produce ultrastructural changes in Lactuca sativa seedlings. S. Afr. J. Bot. 2015, 98, 16-25. [CrossRef]

37. Liu, M.; Lu, S. Plastoquinone and ubiquinone in plants: Biosynthesis, physiological function and metabolic engineering. Front. Plant Sci. 2016, 7, 1-18. [CrossRef]

38. Macias, F.A.; Varela, R.M.; Torres, A.; Galindo, J.L.G.; Molinillo, J.M.G. Allelochemicals from sunflowers: Chemistry, bioactivity and applications. In Chemical Ecology of Plants: Allelopathy in Aquatic and Terrestrial Ecosystems, 1st ed.; Inderjit, Mallik, A.U., Eds.; Springer: Basel, Switzerland, 2002. [CrossRef]

39. Oracz, K.; Bailly, C.; Gniazdowska, A.; Come, D.; Corbineau, F.; Bogatek, R. Induction of oxidative stress by sunflower phytotoxins in germinating mustard seeds. J. Chem. Ecol. 2007, 33, 251-264. [CrossRef]

40. Farhoudi, R.; Lee, D.J. Allelopathic effects of barley (Hordeum vulgare) on sucrose synthase activity, lipid peroxidation and antioxidant enzymatic activities of Hordeum spontoneum and Avena ludoviciana. Proc. Natl. Acad. Sci. India B. 2013, 83, 447-452. [CrossRef]

41. Talukdar, D. Allelopathic effects of Lantana camara L. on Lathyrus sativus L.: Oxidative imbalance and cytogenetic consequences. Allelopath. J. 2013, 31, 71-90.

42. Devi, S.R.; Prasad, M.N.V. Ferulic acid mediated changes in oxidative enzymes of maize seedlings: Implications in growth. Biol. Plant. 1996, 38, 387-395. [CrossRef]

43. Maffei, M.; Bertea, C.M.; Garneri, F.; Scannerini, S. Effect of benzoic acid hydroxy and methoxy ring substituents during cucumber (Cucumis sativus L.) germination. I. Isocitrate lyase and catalase activity. Plant Sci. 1999, 141, 139-147. [CrossRef]

44. Zeng, R.S.; Luo, S.M.; Shi, Y.H.; Shi, M.B.; Tu, C.Y. Physiological and biochemical mechanism of allelopathy of secalonic acid F on higher plants. Agron. J. 2001, 93, 72-79. [CrossRef]

45. Sánchez-Moreiras, A.M.; Reigosa, M.J. Whole plant response of lettuce after root exposure to BOA (2(3H)benzoxazolinone). J. Chem. Ecol. 2005, 31, 2689-2703. [CrossRef] [PubMed]

46. Vainola, A.; Repo, T. Impedance spectroscopy in frost hardiness evaluation of Rhododendron leaves. Ann. Bot. 2000, 86, 799-805. [CrossRef]

47. Pottier-Alapetite, G. Angiospermes-Dicotyledones, Apétales-Dialypétales; Flore de la Tunisie: Tunis, Tunisie, 1979. 
48. Chiapuso, G.; Sanchez, A.M.; Reigosa, M.J.; Gonzaiez, L.; Pellissier, F. Do germination indices adequately reflect allelochemical effects on the germination process? J. Chem. Ecol. 1997, 23, 2445-2453. [CrossRef]

49. Chung, I.M.; Ahn, J.K.; Yun, S.J. Assessment of allelopathic potential of barnyardgrass (Echinochloa crus-galli) on rice (Oryza sativa L.) cultivars. Crop Prot. 2001, 20, 921-928. [CrossRef]

50. Koodkaew, I.; Sunohara, Y.; Matsuyama, S.; Matsumoto, H. Phytotoxic action mechanism of hapalocyclamide in lettuce seedlings. Plant Physiol. Biochem. 2012, 58, 23-28. [CrossRef]

51. Shalata, A.; Neumann, P.M. Exogenous ascorbic acid (vitamin C) increases resistance to salt stress and reduces lipid peroxidation. J. Exp. Bot. 2001, 52, 2207-2211. [CrossRef]

52. Alia, K.V.; Prasad, S.K.; Pardha, S.P. Effect of zinc on free radicals and proline in Brassica and Cajanus. Phytochemistry 1995, 42, 45-47. [CrossRef]

53. Velikova, V.; Yordanov, I.; Edreva, A. Oxidative stress and some antioxidant systems in acid rain-treated bean plants: Protective role of exogenous polyamines. Plant Sci. 2000, 151, 59-66. [CrossRef]

54. Giannopolitis, C.N.; Ries, S.K. Superoxide dismutases: I. Occurrence in higher plants. Plant Physiol. 1977, 59, 309-314. [CrossRef]

55. Cakmak, I.; Marschner, H. Magnesium deficiency and high light intensity enhance activities of superoxide dismutase, ascorbate peroxidase and glutathione reductase in bean leaves. Plant Physiol. 1992, 98, 1222-1227. [CrossRef] [PubMed]

56. Nakano, Y.; Asada, K. Hydrogen peroxide is scavenged by ascorbate-specific peroxidase in spinach chloroplasts. Plant Cell Physiol. 1981, 22, 867-888. [CrossRef]

Sample Availability: Samples of the compounds are not available from the authors.

(C) 2020 by the authors. Licensee MDPI, Basel, Switzerland. This article is an open access article distributed under the terms and conditions of the Creative Commons Attribution (CC BY) license (http://creativecommons.org/licenses/by/4.0/). 